\title{
PERAN KEPALA SEKOLAH SEBAGAI SUPERVISOR DALAM MENINGKATKAN MUTU PENDIDIKAN
}

\author{
Oleh: Astuti \\ Dosen STAIN Watampone
}

\begin{abstract}
This paper discusses the role of the principal as a supervisor in improving the quality of education. Principals as leaders of educational institutions should be responsible for all school / madrasah activities. He has full authority and responsibility to conduct all educational activities including supervision activities, both academic supervision and managerial supervision within the school / madrasah he leads. Principal As Supervisor serves to guide, assist and direct educators and educational staff to appreciate and implement the procedures of education to support the quality of education.
\end{abstract}

Kata Kunci: Peran kepala sekolah sebagai supervisor dan kualitas pendidikan.

Lembaga pendidikan dapat dikategorikan sebagai organisasi nirlaba yang melayani masyarakat. Meski pun sifatnya nirlaba, namun bukan berarti sekolah tidak dituntut untuk terus meningkatkan mutu proses maupun output pendidikannya. Sebaliknya, sekolah sangat diharapkan benar-benar memerhatikan mutu, karena tugas suci yang diembannya adalah turut mencerdaskan kehidupan bangsa, dan meningkatkan kualitas sumber daya manusia Indonesia.

Dalam menjaga mutu proses tersebut, diperlukan adanya quality controll yang mengawasi jalannya proses dan segala komponen pendukungnya. Meski demikian pengawasan mutu dalam dunia pendidikan tentu berbeda dengan peruasahaan yang memproduksi barang/jasa. Sekolah adalah sebuah people changing institution, yang dalam proses kerjanya selalu berhadapan dengan uncertainty and interdependence. Maksudnya mekanisme kerja (produksi) di lembaga pendidikan secara teknologis tidak dapat dipastikan karena kondisi input dan lingkungan yang tidak pernah 
sama. Selain itu proses pendidikan di sekolah juga tidak terpisahkan dengan lingkungan keluarga maupun pergaulan peserta didik.

Dalam situasi demikian, maka pengawasan terhadap sekolah pasti berbeda model dan pendekatannya. Peran seorang pengawas pendidikan pun tentu berbeda dengan pengawas pada perusahaan produksi. Kepala sekolah sebagai supervisor harus mampu berperan sebagai konsultan dalam manajemen sekolah, pengembangan kurikulum, teknologi pembelajaran, dan pengembangan staf. Ia harus memberikan pelayanan baik secara kelompok maupun individual. Ada kalanya supervisor harus berperan sebagai pemimpin kelompok dalam pertemuan-pertemuan yang berkaitan dengan pengembangan kurikulum, pembelajaran atau manajemen sekolah secara umum. Terakhir, supervisor juga harus melakukan evaluasi terhadap pengelolaan sekolah dan pembelajaran pada sekolah-sekolah yang menjadi lingkup tugasnya.

\section{Kepemimpinan Kepala Sekolah}

Kepemimpinan merupakan salah satu topik yang selalu menarik untuk dikaji dan diteliti, karena paling banya diamati dan sekaligus fenomena yang paling sedikit dipahami.

Istilah kepemimpinan (leadership) berasal dari kata leader artinya pemimpin atau lead artinya memimpin. Leadership sudah menjadi kajian tersendiri dalam ilmu manajemen. Sebagian besar teori menjelaskan definisi kepemimpinan mencerminkan asumsi bahwa kepemimpinan berkaitan dengan proses yang disengaja dari seseorang untuk menekankan ppengaruhnya yang kuat terhadap orang lain untuk membimbing, membuat struktur, serta menfasilitasi aktivitas dan hubungan di dalam kelompok atau terlihat kesamaannya. Definisi berbeda dalam berbagai hal, termasuk siapa yang bisa menanamkan pengaruhnya, dan hasil dari pengaruh itu sendiri.

Jika ditelaah berbagai sumber akan dijumpai pengertian-pengertian yang berbeda mengenai kepemimpinan, tergantung dari jenis sumbernya dan yang merumuskan pengertian tersebut. Para peneliti biasanya mendefinisikan kepemimpinan menurut pandangan pribadi mereka, serta aspek-aspek fenomena dari kepentingan yang paling baik bagi para pakar yang bersangkutan. 
Stogdil mengatakan: "There are almost as many defenitions of leadership as there are persons who have attempted to define the concept" (jumlah definisi kepemimpinan hampir sama banyak dengan orang yang mencoba mendefinisikan konsep itu). ${ }^{1}$

Walaupun demikian, tampaknya ada kata sepakat bahwa kepemimpinan mencakup suatu proses pengarhu, seperti yang dikatakan Stephen P.Robbins:" Leadership as the ability to influence agroup toward the achievement of goals." ${ }^{2}$ Dengan demikian, kepemimpinan merupakan proses mempengaruhi untuk mencapai suatu masa depan suatu organisasi.

Kepemimpinan diterjemahkan ke dalam istilah: sifat-sifat, perilaku pribadi, pengaruh terhadap orang lain, pola-pola interaksi, hubungan antar kerjasama antar peran, kedudukan dari suatu jabatan administratif, dan persepsi dari lain-lain tentang legitimasi pengaruh. ${ }^{3}$

Menurut Soejorno Soekamto Kepemimpinan (leadership) adalah kemampuan seseorang (yaitu pemimpin atau leader) untuk mempengaruhi orang lain (yaitu yang dipimpin atau pengikut-pengikutnya) sehingga orang lain tersebut bertingkah laku sebagaimana dikehendaki oleh pemimpin. ${ }^{4}$

Dari uraian di atas dapat disimpulkan bahwa kepemimpinan merupakan kemampuan sesorang untuk mempengaruhi orang lain dengan pendekatan sifat, prilaku, pola interaksi,dan kedudukan sehingga perbuatannya mengarah pada pencapaian tujuan organisasi.

Kepala sekolah sebagai pemimpin lembaga pendidikan harus bertanggung jawab terhadap seluruh kegiatan-kegiatan sekolah. Ia mempunyai wewenang dan tanggung jawab penuh untuk menyelenggarakan seluruh kegiatan pendidikan dalam lingkungan sekolah yan dipimpinnya.

Kepala sekolah tidak hanya bertanggung jawab atas kelancaran jalannya sekolah secara teknis akademis saja, akan tetapi segala kegiatan,

\footnotetext{
${ }^{1}$ Ralp M Stogdill, Handbook of Leadership: A survey of the literature, New York Free Press, 1974, h. 259.

${ }^{2}$ Stephen P. Robbins, Organizational Behavior, Mexico: Prentice Hall, 2003, h. 314

${ }^{3}$ Wahyosumidjo, Kepemimpinan Kepala Sekolah (Jakarta : PT Raja Grafindo Persada, 2003), h. 17.

${ }^{4}$ Soerjono Soerkamto, Sosiologi Suatu Pengajar (Jakarta : PT. Grafindo Persada, 1990), h. 318.
} 
keadaan lingkungan sekolah dan kondisi dan situasinya serta hubungan dengan masyarakat sekitarnya merupakan tanggung jawabnya pula.

Pandangan tersebut menganjurkan kepada para kepala sekolah/madrasah untuk memahami tugas pokok dan fungsinya sebagai pemimpin pendidikan secara cermat sehingga kepemimpinannya efektif dalam arti tercapai tujuan yang diharapkan.

\section{Fungsi dan Tanggung Jawab Kepala sekolah}

Kepala sekolah merupakan personel sekolah yang bertanggung jawab terhadap seluruh kegiatan-kegiatan sekolah. Ia mempunyai wewenang dan tanggung jawab penuh untuk menyelenggarakan seluruh kegiatan pendidikan dalam lingkungan sekolah yang dipimpinnya dengan dasar Pancasila dan UUD 1945.

Kepala sekolah tidak hanya bertanggung jawab atas kelancaran jalannya sekolah secara teknis akademis saja, akan tetapi segala kegiatan, keadaan lingkungan sekolah dengan kondisi dan situasinya serta hubungannya dengan masyarakat sekitarnya merupakan tanggung jawabnya pula. Inisiatif dan kreatif yang mengarahkan kepada perkembangan dan kemajuan sekolah adalah merupakan tugas dan tanggung jawab kepala sekolah. Namun demikian, dalam usaha memajukan sekolah dan menanggulangi kesulitan yang dialami sekolah baik yang berupa atau bersifat material seperti perbaikan gedung, penambahan ruang, penambahan perlengkapan dan sebagainya maupun yang bersangkutan dengan pendidikan anak-anak, kepala sekolah tidak dapat bekerja sendiri. Kepala sekolah harus mengadakan kerjasama dengan personal sekolah.

Menurut H.M. Daryanto, bahwa kegiatan sekolah yang menjadi tanggung jawab kepala sekolah, yaitu:

a. Kegiatan mengatur proses belajar mengajar.

b. Kegiatan mengatur kesiswaan.

c. Kegiatan mengatur personalia.

d. Kegiatan mengatur peralatan pengajaran.

e. Kegiatan mengatur dan memelihara gedung dan perlengkapan sekolah.

f. Kegiatan mengatur keuangan. 
g. Kegiatan mengatur hubungan antara sekolah dan masyarakat. ${ }^{5}$

Menurut E. Mulyasa, dalam paradigma baru manajemen pendidikan, kepala sekolah setidaknya harus mampu berfungsi sebagai;

a. Edukator (pendidik);

b. Manajer;

c. Administrator;

d. Supervisor;

e. Leader (pemimpin);

f. Innovator;

g. Motivator. $^{6}$

Kepala sekolah sebagai edukator harus memiliki strategi yang tepat untuk meningkatkan profesionalisme tenaga pendidik di sekolahnya, menciptakan iklim sekolah yang kondusif, memberikan nasehat kepada warga sekolah,memberikan dorongan kepada seluruh tenaga pendidik serta melaksanakan model pembelajaran yang menarik. Kepala sekolah harus berusaha menanamkan, memajukan dan meningkatkan sedikitnya empat macam nilai menurut E. Mulyasa yaitu pembinaan mental, moral, fisik dan artistik. $^{7}$

Pembinaan mental adalah membina para tenaga pendidik tentang sikap batin dan watak. Pembinaan moral adalah pembinaan tentang perbuatan baiik dan buruk, sikap dan kewajiban sesuai dengan tugas masingmasing. Pembinaan fisik adalah pembinaan jasmani, kesehatan dan penampilan, sedangkan pembinaan artistik adalah pembinaan tentang kepekaan terhadap seni dan keindahan. Dalam rangka meningkatkan kinerja sebagai edukator, kepala sekolah harus merencanakan dan melaksanakan program sekolah dengan baik, antara lain :

a. Mengikutkan tenaga pendidik dalam penataran guna menambah wawasan, juga memberi kesempatan kepada tenaga pendidik untuk meningkatkan pengetahuan dan keterampilannya dengan belajar ke jenjang yang lebih tinggi.

${ }^{5}$ H.M. Daryanto, Administrasi Pendidikan (Jakarta : Rineka Cipta, 2005), h. 80.

${ }^{6}$ E. Mulyasa, Menjadi Kepala Sekolah Profesional (Cet: X; Bandung: Remaja Rosdakarya, 2009), h. 98.

${ }^{7}$ Ibid. 
b. Menggerakkan tim evaluasi hasil belajar untuk memotivasi peserta didik agar lebih giat belajar dan meningkatkan prestasinya.

c. Menggunakan waktu belajar secara efektif di sekolah dengan menekankan disiplin yang tinggi. ${ }^{8}$

Kegiatan belajar mengajar merupakan inti dari proses pendidikan dan guru merupakan pelaksana dan pengembang utama kurikulum di sekolah, kepala sekolah yang menunjukkan komitmen tinggi dan fokus terhadap pengembangan kurikulum dan kegiatan belajar mengajar di sekolahnya tentu akan sangat memperhatikan tingkat kompetensi yang dimiliki gurunya, sekaligus juga akan senantiasa berusaha memfalisitasi dan mendorong agar para guru dapat secara terus menerus meningkatkan kompetensinya, sehingga kegiatan belajar mengajar dapat berjalan efektif dan efisien.

Kepala Sekolah Sebagai Manajer mempunyai tugas merencanakan, mengorganisasikan, mengatur, mengkoordinasikan dan mengendalikan dalam rangka mencapai tujuan yang telah ditetapkan. ${ }^{9}$ Merencanaan menurut Roger A.Kaiffman adalah proses penentuan tujuan atau sasaran yang hendak dicapai dan menetapkan jalan dan sumber yang diperlukan untuk mencapai tujuan itu seefisien dan seefektif yang tidak dapat dipisahkan antara satu dengan kegiatan dengan kegiatan yang lainya. Kegiatan tersebut adalah perumusan tujuan yang ingin dicapai dan pemilihan program untuk mencapai tujuan itu.

Dengan demikian, kepala sekolah harus mampu merencanakan dan mengatur serta mengendalikan semua program yang telah disepakati bersama. Dalam mengelola tenaga pendidikan, salah satu tugas penting yang harus dilakukan kepala sekolah adalah melaksanakan kegiatan pemeliharaan dan pengembangan profesi para guru. Dalam hal ini kepala sekolah seyogyanya dapat memfasilitasi dan memberikan kesempatan yang luas kepada guru untuk melaksanakan kegiatan pengembangan profesi melalui berbagai kegiatan pendidikan dan pelatihan, baik yag dilaksanakan sekolah, seperti : MGMP/MGP tingkat sekolah, in house training, diskusi profesional dan sebagainya, atau melalui kegiatan pendidikan dan pelatihan diluar

${ }^{8}$ Ibid, h. 103.

${ }^{9}$ Nanang Fattah Landasan Manajemen Pendidikan, (Cet.VII; Bandung: PT. Remaja Rosdakarya Offset. 2004), h. 49 
sekolah, seperti : kesempatan melanjutkan pendidikan atau mengikuti berbagai kegiatan pelatihan yang diselenggarakan pihak lain.

Kepala sekolah sebagai administrator sangat diperlukan karena kegiatan disekolah tidak terlepas dari pengelolaan administrasi yang bersifat pencatatan dan pendokumentasian seluruh program sekolah. Dalam menjalankan fungsinya sebagai administrator, kepala sekolah harus mampu menguasai tugas-tugasnya dan menjalankan tugasnya dengan baik. Ia bertanggung jawab terhadap seluruh kegiatan sekolah, mengatur hal yang menyangkut kesiswaan, sarana dan prasarana, yang dibutuhkan dalam pelajaran, ketatausahaan, kurikulum serta mengatur hubungan dengan masyarakat. ${ }^{10}$ Kegiatan tersebut perlu dilakukan secara efektif agar administrasi sekolah dapat tertata dan terlaksana dengan baik. Kemampuan kepala sekolah sebagai administrator harus diwujudkan dalam penyusunan kelengkapan data administrasi pembelajaran, bimbingan dan konseling, kegiatan praktikum, kegiatan di perpustakaan, data administrasi peserta didik, guru, pegawai TU, penjaga sekolah, teknisi dan pustakawan, kegiatan ekstrakurikuler, data administrasi hubungan sekolah dengan orang tua murid, data administrasi gedung dan ruang dan surat menyurat. Kepala sekolah sebagai administrator dalam hal ini juga berkenaan dengan keuangan, bahwa untuk tercapainya peningkatan kompetensi guru tidak lepas dari faktor biaya. Seberapa besar sekolah dapat mengalokasikan anggaran peningkatan kompetensi guru tentunya akan mempengaruhi terhadap tingkat kompetensi para gurunya. Masalah keuangan adalah masalah yang peka. Oleh karena itu, dalam mengelola bidang ini kepala sekolah harus hati-hati, jujur dan terbuka agar tidak timbul kecurigaan baik dari staf maupun dari masyarakat atau orang tua murid. Banyak keperluan sekolah yang harus dibiayai, dan semakin banyak pula biaya yang diperlukan. Dalam hal ini kepala sekolah harus memiliki daya kreasi yang tinggi untuk mampu menggali dana dari berbagai sumber, diantaranya dapat diperoleh misalnya dari siswa atau orang tua, masyarakat, pemerintah, yayasan, para dermawan dan sebagainya. Disamping itu kepala sekolah juga harus mampu mengalokasikan dana atau anggaran yang memadai bagi upaya peningkatan sekolah/madrasah.

\footnotetext{
${ }^{10}$ Yusak Burhanuddin, Administrasi Pendidikan (Cet. I; Bandung: CV. Pustaka Setia,199), h, 140.
} 
Kepala Sekolah Sebagai Supervisor berfungsi untuk membimbing, membantu dan mengarahkan tenaga pendidik dan tenaga kependidikan untuk menghargai dan melaksanakan prosedur-prosedur pendidikan guna menunjang kemajuan pendidikan. Kepala sekolah juga harus mampu melakukan berbagai pengawasan dan pengendalian untuk meningkatkan kinerja tenaga pendidik. Hal ini dilakukan sebagai tindakan preventif untuk mencegah agar para tenaga pendidik tidak melakukan penyimpangan dan lebih hati-hati dalam melaksanakan tugasnya. Untuk mengetahui sejauh mana guru mampu melaksanakan pembelajaran, secara berkala kepala sekolah perlu melaksanakan kegiatan supervisi, yang dapat dilakukan meliputi kegiatan kunjungan kelas untuk mengamati proses pembelajaran secara langsung, terutama dalam pemilihan dan penggunaan metode, media yang digunakan dan keterlibatan siswa dalam proses pembelajaran. Dari hasil supervisi ini, dapat diketahui kelemahan sekaligus keunggulan guru dalam melaksanakan pembelajaran, tingkat penguasaan kompetensi guru yang bersangkutan, selanjutnya diupayakan solusi, pembinaan dan tindak lanjut tertentu sehingga guru dapat memperbaiki kekurangan yang ada sekaligus mempertahankan keunggulannya dalam melaksanakan pembelajaran.

Kepala sekolah sebagai leader (pemimpin). Dalam teori kepemimpinan setidaknya kita mengenal dua gaya kepemimpinan yaitu kepemimpinan yang berorientasi pada tugas dan kepemimpinan yang berorientasi pada manusia. Dalam rangka meningkatkan kompetensi guru, seorang kepala sekolah dapat menerapkan kedua gaya kepemimpinan tersebut secara tepat dan fleksibel, disesuaikan dengan kondisi dan kebutuhan yang ada.Kepemimpinannya tersebut harus didukung dengan kepribadian yang baik.

Sejauh mana kepala sekolah dapat mewujudkan peran-peran di atas, secara langsung maupun tidak langsung dapat memberikan kontribusi terhadap peningkatan kompetensi seluruh komponen pendidikan, yang pada gilirannya dapat membawa efek terhadap peningkatan mutu pendidikan di sekolah. 


\section{Peran kepala sekolah sebagai supervisor dalam meningkatkan kualitas pendidikan}

Kepala sekolah sebagai supervisor harus diwujudkan dalam kemampuan penyusun dan melaksanakan program supervisi pendidikan serta memanfaatkan hasilnya. Kemampuan menyusun program supervisi pendidikan harus diwujudkan dalam penyusunan program supervisi kelas, pengembangan program supervisi untuk kegiatan ekstra kurikuler, pengembangan program supervisi perpustakaan, laboratorium, dan ujian. Kemampuan melaksanakan program supervise Kepala sekolah dalam kedudukannya sebagai supervisor berkewajiban membina para guru agar menjadi pendidik dan pengajar yang baik. Bagi guru yang sudah baik agar dapat dipertahankan kualiasnya dan bagi guru yang belum baik dapat dikembangkan menjadi lebih baik. Sementara itu, semua guru yang baik dan sudah berkompeten maupun yang masih lemah harus diupayakan agar tidak ketinggalan jaman dalam proses pembelajaran maupun materi yang menjadi bahanajar.

Agar pelaksanaan tugas-tugas itu dapat dikerjakan dengan baik, maka kepala sekolah dituntut mempunyai berbagai cara dan teknik supervisi terutama yang berhubunganya dengan pelaksanaan tugas-tugas guru dan karyawan, dan pertumbuhan jabatan. Karena kepala sekolah sebagai pemimpin utama dan penggerak dalam pelaksanaan pendidikan dan pembelajaran.

Kepala sekolah dalam pelaksanaan tugas sebagai supervisor, hendaknya dilaksanakan dengan demokratis ia menghargai pendapat guru, dan memberikan kesempatan untuk melahirkan gagasan dan pendapat. Keputusan yang di ambil dengan jalan musyawarah, karena tujuan yang hendak dicapai adalah tujuan bersama.

Hal-hal yang perlu diperhatikan dan perlu dikembangakan pada setiap guru oleh kepala sekolah sebagai supervisor adalah kepribadian guru, peningkatan profesi secara kontinue, proses pembelajaran, penguasaan materi pelajaran, keragaman kemampuan guru, keragaman daerah, dan kemampuan guru dalam bekerjasama dengan masyarakat.

Kepala sekolah sebagai supervisor atau pengawas yang tugaskan di lembaga Depag maupun Diknas, harus benar-benar mengerti bantuan apa 
yang sebenarnya dibutuhkan oleh guru dalam melaksanakan dan meningkatkan kualitas profesionalnya. Meningkatkan mutu pembelajaran menjadi landasan profesionalisme supervisi pendidikan. Karenanya diperlukan perubahan dan pengembangan visi berorientasi pada mutu, kecerdasan siswa, dan paradigma baru pendidikan.

Pengawas adalah orang yang diberi tanggung jawab tugas dan tanggung jawab oleh pejabat yang berwenang untuk melaksanakan kepengawasan akademik dan pengawasan manajerial pada satuan pendidikan/sekolah.

Supervisi berfungsi membantu (assiting) memberi support (supporting) dan mengajak mengikutsertakan (sharing). Dilihat dari fungsinya, tampak dengan jelas peranan supervisi itu. Peranan itu tampak dalam kinerja supervisor yang melaksanakan tugasnya. Mengenai peranan supervisi dapat dikemukakan berbagai pendapat para ahli. Menurut Peter F. Olivia Seorang supervisor berperan sebagai:

1. Sebagai koordinator ia dapat mengkoordinasikan program belajar mengajar, tugas-tugas anggota staf sebagai kegiatan yang berbedabeda di antara guru-guru. Contoh konkret mengkoordinasi tugas satu mata pelajar yang dibina oleh berbagai guru.

2. Sebagai konsultan ia dapat memberi bantuan, bersama mengkonsultasikan masalah yang dialami guru baik secara individual maupun secara kelompok. Misalnya, kesulitan dalam mengatasi dalam tahap muka kelas.

3. Sebagai pemimpin kelompok ia dapat memimpin sejumlah staf mengembangkan kurikulum, materi pelajaran dan kebutuhan prifesional guru-guru secara bersama. Sebagai pemimpin kelompok ia dapat mengembangkan keterampilan dari kiat-kiat dalam bekerja untuk kelompok, bekerja dengan kelompok dan bekerja melalui kelompok.

4. Sebagai evaluator ia dapat membantu guru-guru dalam menilai hasil dan proses belajar, dapat menilai kurikulum yang sedang dikembangkan. Ia juga belajar menata dirinya sendiri. Ia dibantu dalam merefleksi dirinya yaitu, konsep diri, ide/cita-cita dirinya, realitas dirinya. Misalnya diakhir semester ia dapat mengadakan evaluasi diri sendiri dengan memperoleh umpan balik dari setiap 
peserta didik yang dapat dipakai sebagai bahan untuk memperbaiki dan meningkatkan dirinya.

Dalam konteks peningkatan mutu pendidikan sejalan dengan PP No.

19 Tahun 2005 tentang standar mutu pendidikan, peranan pengawas satuan pendidikan/sekolah sangat penting dalam meningkatkan mutu pendidikan pada satuan pendidikan binaannya. Keberadaan pengawas sekolah/ satuan pendidikan memegang peranan penting dalam membina dan mengembangkan kemampuan profesional tenaga pendidik (guru), kepala sekolah dan staf lainnya agar sekolah yang dibinanya dapat meningkatkan mutu pendidikan.

Menurut Keputusan Menteri P dan K RI No. 0134/0/1977, tugas pengawas dalam pendidikan di rinci sebagai berikut:

1. Mengendalikan pelaksanaan kurikulum meliputi isi, metode penyajian, penggunaan alat perlengkapan dan penilainnya agar berlangsung sesuai dengan ketentuan dan peraturan perundangundangan yang berlaku.

2. Pengendalian tenaga teknik sekolah agar terpenuhi persyaratan formal yang berlaku dan melaksanakan tugasnya sesuai dengan ketentuan dan peraturan perundang-undangan yang berlaku.

3. Mengendalikan pengadaan, penggunaan dan pemeliharaan sarana sekolah sesuai dengan ketentuan dan peraturan perundang-undangan yang berlaku serta menjaga kualitas dan kuantitas sarana sekolah memenuhi ketentuan dan persyaratan yang berlaku.

4. Mengendalikan tata usaha sekolah meliputi urusan kepegawaian, urusan keuangan dan urusan perkantoran agar berjalan sesuai dengan ketentuan dan peraturan perundang-undangan yang berlaku.

5. Mengendalikan hubungan kerja sama dengan masyarakat, antara lain dengan pemerintah daerah, dunia usaha, dan lain-lain.

6. Menilai proses dan hasil pelaksanaan kurikulum berdasarkan ketetapan dan waktu.

7. Menilai pelaksanaan kerja tenaga teknik sekolah.

8. Menilai pemanfaatan sarana sekolah.

9. Menilai efesiensi dan efektifitas tata usaha sekolah.

10. Menilai hubungan kerja dengan masyarakat, antara lain pemerintah daerah, dunia usaha, dan lain-lain. 
11. Melaksanakan program supervisi sekolah serta memberikan petunjuk perbaikan terhadap penyimpangan dalam pengelolaan sekolah yang meliputi segi:

a. Proses dan hasil pelaksanaan kurikulum yang dicapai pada periode tertentu. Kegiatan sekolah di bidang pengelolaan gedung dan bangunan, halaman, perabot dan alat-alat kantor dan sarana pendidikan lainnya.

b. Pengembangan personel sekolah termasuk kepala sekolah, guru, tenaga tata usaha yang mencakup segi disiplin, sikap dan tingkah laku, pembinaan karier, peningkatan pengetahuan dan keterampilan sesuai dengan tuntutan profesi masing-masing.

c. Tata usaha sekolah termasuk urusan keuangan, urusan sarana, dan urusan kepegawaian.

d. Hubunagan sekolah dengan Badan Pembantu Penyelenggaraan Pendidikan dan masyarakat pada umumnya. ${ }^{11}$

Untuk mewujudkan mutu pendidikan di sekolah/madrasah, maka kepala sekolah/madrasah harus melaksanakan pengawasan akademik dan pengawasan manajerial dengan berdasarkan perinsip manusiawi, berkesinambungan, demokratis, integral, komprehensif, obyektif, dan konstruktif.

Mutu merupakan hal yang sangat penting dalam berbagai bidang termasuk pendidikan. Mutu dalam konsep Daming ialah kesesuaian dengan kebutuhan pasar. Fiegenbaum mengertikan mutu sebagai kepuasan pelanggan sepenuhnya (full customer satisfaction). ${ }^{12}$ Sedangkan Sudarwan Danim mengatakan, mutu mengandung makna derajat keunggulan suatu produk atau hasil kerja, baik berupa barang dan jasa. ${ }^{13}$

Sekolah ataupun madrash bermutu menjadi kebutuhan yang sangat penting dalam penyiapan sumber daya manusia yang handal. Sumber daya manusia yang handal, menjadi tumpuan harapan kemajuan suatu bangsa dan

\footnotetext{
${ }^{11}$ M. Ngalim Purwanto, Administrasi dan Supervisi Pendidikan, (Cet. 21. Bandung: Remaja Rosdakarya, 2012), h. 78.

${ }^{12}$ Husaini Usman, manajemen: Teori, Praktik, dan Riset pendidikan Pendidikan (Jakarta: Bumi Aksara, 2006), h, 410.

${ }^{13}$ Sudarwan Danim, Visi Baru Manajemen Sekolah (Jakarta: Bumi Aksara, 2007), h. 53.
} 
secara khusus menjadi harapan bagi lembaga pendidikan. Berbicara mutu pendidikan di sekolah/madrasah tidak terlepas dari mutu input, proses, dan output. Hakikat mutu juga tidak terlepas dari penilaian tentang sesuatu hal dalam memenuhi kriteria atau standar tertentu.

Seluruh manajemen komponen pendidikan harus senantiasa berorientasi pada pencapaiann mutu pendidikan. Semua program dan kegiatan pendidikan serta pembelajaran di lembaga pendidikan pada hakikatnya harus bisa diarahkan pada pencapaian mutu.. Walaupun hingga saat ini, persoalan mutu masih menjadi pembahastan ditataran idealism, belum menjadi realitas dalam lembaga pendidikan, sehingga mutu pendidikan ini benar-benar misterius. Maka perlu dikerahkan semua pikiran, tenaga dan strategis untuk mewujudkan mutu tersebut dalam lembaga pendidikan, termasuk lembaga pendidikan Islam.

\section{PENUTUP}

Kepemimpinan merupakan kemampuan sesorang untuk mempengaruhi orang lain sehingga perbuatannya mengarah pada pencapaian tujuan. Kepala sekolah merupakan personel sekolah yang bertanggung jawab terhadap seluruh kegiatan-kegiatan sekolah. Ia mempunyai wewenang dan tanggung jawab penuh untuk menyelenggarakan seluruh kegiatan pendidikan dalam lingkungan sekolah.

Kepala Sekolah Sebagai Supervisor berfungsi untuk membimbing, membantu dan mengarahkan tenaga pendidik dan tenaga kependidikan untuk menghargai dan melaksanakan prosedur-prosedur pendidikan guna menunjang terwujudnya mutu pendidikan. Berbicara mutu pendidikan di sekolah/madrasah tidak terlepas dari mutu input, proses, dan output.

\section{DAFTAR RUJUKAN}

Burhanuddin, Yusak. 1999. Burhanuddin, Administrasi Pendidikan. Bandung: CV.Pustaka Setia.

Danim, Sudarwan. 2007. Visi Baru manajemen sekolah. Jakarta: Bumi Aksara, 
Daryanto H.M..2005. Administrasi Pendidikan. Jakarta : Rineka Cipta.

Fattah, Nanang. 2009. Landasan Manajemen Pendidikan. Bandung: PT. Remaja Rosdakarya Offset.

Kurniadin, Didin dan Imam Machali. 2012 Manajemen Pendidikan. Konsep \& Prinsip Pengelolaan Pendidikan. Jogjakarta: AR-RUZZ MEDIA.

M Stogdill.1974. Handbook of Leadership: A survey of the literature, New York Free Press.

Muhaimin,dkk. 2010. Manajemen Pendidikan Aplikasinya dalam Penyusunan Rencana Pengembangan Sekolah Madrasah. Jakarta: Kencana Prenada Media Group.

Mulyasa, E. 2009 Menjadi Kepala Sekolah Profesional. Bandung: Remaja Rosdakarya.

Purwanto,M. Ngalim. 2012 Administrasi dan Supervisi Pendidikan. t. 21. Bandung: Remaja Rosdakarya.

Qomar, Mujamil. 2007. Manajemen Pendidikan Islam. Eelangga.

Sahertian Piet. A. 2000.Konsep Dasar dan Teknik Supervisi Pendidikan Dalam Rangka Pengembangan Sumber Daya Manusia. Jakarta: Ahdi Mahasatya.

Stephen P. Robbins.2003. Organizational Behavior, Mexico: Prentice Hall.

Sugiyono. 2013. Metodologi Penelitian Manajemen. Bandung: Alfabeta.

Suhartono, Nugraha. 2013, Manajemen Pendidikan. Bandung, alfabeta. 
Ukas, Maman. 1999. Manajemen: Konsep, Prinsip, dan Aplikasi. Bandung: Ossa Promo.

Usman, Husaini. 2006. Manajemen: Teori, Praktik, dan Riset pendidikan Pendidikan. Jakarta: Bumi Aksara.

Wahyosumidjo. 2003. Kepemimpinan Kepala Sekolah. Jakarta : PT Raja Grafindo Persada. 